1) топонимического предания, подкрепленного соответствующими топонимами, призванными подчеркнуть «реальный» характер информации, 2) эпизода из сказки, 3) эпического сказания. На этой основе можно сделать вывод о существовании в прошлом эпического цикла о священной горе Бурхох, основная тема которого - жизнь первых людей в эпоху «золотого века», очевидно, питавшихся чудесным напитком, похищение которого, скорее всего, и ознаменовало конец этого века.

DOI 10.31168/7996-2700-3.39

\author{
Е. В. Дзюба*, С. А. Еремина** \\ Уральский государственный педагогический университет \\ Екатеринбург, Россия \\ *elenacz@mail.ru \\ **swegle@yandex.ru
}

\title{
О феномене вторичной русскоязычной самономинации у китайских студентов*
}

При обучении китайских студентов русскому языку как иностранному преподаватели сталкиваются с интересным феноменом вторичной самономинацией, выбором иностранными учащимися второго - русского - имени. Обычно имя выбирается студентами еще в начале обучения языку в университетах Китая; русские имена берут себе и китайские преподаватели, ведущие отдельные курсы по русскому языку.

Такой шаг студенты и преподаватели объясняют трудностью восприятия и произношения китайского личного имени русскими коллегами, опасениями искажения фонетического облика имени собственного, ведущего к серьезным семантическим изменениям. Выбор второго имени связан также с желанием приобщиться к русской культуре и быть толерантными.

С целью определить мотивировочные признаки, лежащие в основе выбора русскоязычного имени собственного у иностранцев, была

\footnotetext{
* Исследование выполнено при финансовой поддержке РФФИ, научный проект № 19013-00895.

(C) Дзюба Е. В., Еремина С. А., 2019
} 
разработана анкета, предлагающая изучающим русский язык китайцам - студентам Уральского государственного педагогического университета (Екатеринбург) ответить на следующие вопросы:

1. Ваше китайское имя (русскими буквами).

2. Что означает ваше имя в переводе с китайского языка?

3. Кто из родителей дал вам китайское имя?

4. Почему ваши родители выбрали это имя? (Потому что так называли родственников или известных людей, или это имя отражает вашу внешность и т. п.)

5. Вам нравится или не нравится ваше имя? Почему?

6. Ваше русское имя.

7. Вы сами выбирали себе русское имя?

8. Почему вы выбрали это русское имя?

9. Почему вы согласились взять это русское имя?

10. Вы отзываетесь на другие варианты вашего русского имени (например: Мария - Маша, Машенька...)?

11. Какие другие русские имена вам нравятся? Почему?

Ответы респондентов показали, что процесс вторичной самономинации осуществляется на основании следующих мотивировочных интенций.

\section{1. Фонетический облик имени собственного}

1.1. Выбор нового имени осуществляется на основании фонетической близости родного и русского имени (общности некоторых звуков или звукосочетаний), ср.: студент по имени Пан Хао выбирает имя Петр (общность начального звука), Мин Лео выбирает имя Виола (общность некоторых звуков) и т. п.

1.2. Выбор нового имени обусловлен благозвучием, гармоничностью (по субъективному мнению носителей китайского языка) звучания. Так, благодаря «приятному», по мнению иностранцев, звучанию приоритетными для выбора оказываются имена Аврора, Анна, Андрей, Виктор, Ира, Наташа, Пульхерия и др.

1.3. Выбор нового имени диктуется краткостью написания и произношения: «Зоя. Потому что это имя очень короткое». Эту причину выбора имени можно объяснить явлением интерференции: носителям моносиллабических языков сложно воспринимать и произносить многосложные русские слова. 


\section{2. Семантические характеристики имени собственного}

2.1. Выбор нового имени определяется семантикой этимона русского имени, ср.: «Софья. Это хорошее имя. Оно обозначает 'умная, мудрая'»; «Мне нравится имя Надежда, оно имеет хорошее значение. Я надеюсь на хорошую жизнь»; «Мое имя Любовь. Потому что, я думаю, любовь - это хорошо»; «Роза - как цветок».

2.2. Выбор нового имени обусловлен семантической близостью его этимона этимону китайскому имени, ср. в одной из анкет: «Сейчас в России меня зовут Евгений. Мое русское имя я сам выбирал, потому что китайское и русское имя имеют одинаковое значение» (имя студента Лян Чжао, что в переводе с китайского означает 'храбрый, отважный', в языковом сознании студента понятия «храбрый», «отважный» и «благородный» семантически сближены).

\section{3. Лингвокультурная идентификация}

Самономинация определяется связью с именем собственным конкретного человека как феноменом русской культуры, ср.: «Мое имя Катя. Это хорошее имя. Екатерина основала Екатеринбург».

\section{4. Коммуникативно-ситуативная обусловленность вторичной самономинации}

Выбор имени определяется спецификой учебной ситуации: самономинация по имени учителя русского языка; присвоение имени, наиболее частотного в учебниках русского языка как иностранного (Анна, Антон).

\section{5. Общее позитивное восприятие имени}

Нередко студенты не могут отчетливо обозначить причину выбора, отмечая общее положительное впечатление от имени собственного, ср.: «Мое имя Аврора. Я думаю, что оно симпатичное»; «Я выбрала имя Анна. Потому что это милое имя».

Выбранное студентом имя не всегда имеет официальную форму. Саша предпочитается Александру, Рита - Маргарите. Гипокористики часто не воспринимаются китайскими студентами как варианты официального имени, что становится лингводидактической проблемой обучения иностранцев [см. об этом: Супрун, 2017].

Показательно, что любой способ самономинации, лежащий в основе искусственного выбора вторичного русскоязычного имени 
китайскими студентами, сопряжен с позитивным восприятием данной единицы русского языка на всех уровнях - фонетическом, семантическом, асоциативном, уровне положительного коммуникативного опыта, позитивного восприятия отдельных феноменов русской культуры и т. д.

Супрун В. И. Лингвокультурологические и лингводидактические аспекты русской ономастики // Ценности в лингвокультурном аспекте: языковое сознание, коммуникация, текст. Тяньцзинь, 2017. С. 164-171.

DOI $10.31168 / 7996-2700-3.40$

\section{Т. Н. Дмитриева}

Уральский федеральный университет

Екатеринбург, Россия

profdmitan@yandex.ru

\section{К истории и этимологии мансийских топонимов: озеро Ваткатур и смежные объекты}

Памяти Габора Б. Секея посвящается

Озеро Ваткатур (манс. сев. Ва̄тка тӣp) находится на севере Свердловской области, в междуречье Лозьвы и Пелыма, в районе верхнего течения обеих рек, на территории традиционного проживания манси, где преобладает топонимия мансийского происхождения. Это самое крупное озеро в данной местности: его наибольшая длина (с юго-запада на северо-восток) - 2,5 км, ширина (с северо-запада на юго-восток) 2 км; название фиксируется на современных картах.

Сопоставление современных топонимических данных, сведений письменных источников и исторических карт позволяет еще раз обратить внимание на историю функционирования и этимологию названий данного озера и смежных с ним объектов.

1. На рукописных картах Антала Регули середины XIX в., являющихся уникальным источником полевых сведений о топонимии Северного Урала [см.: Секей, 2012; Дмитриева, 2015б; 2017], озеро названо

(c) Дмитриева Т. Н., 2019 